\title{
Influence of Granite Cutting Waste Addition on the Geotechnical
}

\section{Parameters of Cohesive Soil}

\author{
Syed Husnain Ali Shah ${ }^{1}$, Muhammad Arif ${ }^{2,3}$, Muhammad Ehsaan Asif ${ }^{1}$, Muhammad Safdar ${ }^{4}$ \\ ${ }^{1}$ Department of Earth Sciences, COMSATS University Islamabad, Abbottabad Campus, Pakistan \\ ${ }^{2}$ Department of Geology, University of Peshawar, Peshawar, Pakistan \\ ${ }^{3}$ Department of Earth Sciences, Abbottabad University of Science and Technology, Havelian
}

(Abbottabad), Pakistan

${ }^{4}$ Institute of Geology, University of Azad Jammu and Kashmir,Muzaffarabad 31200, Pakistan

\begin{abstract}
The current study analyzes the effect of granite cutting waste addition on the properties of cohesive soil. Representative samples of cohesive soils were collected from the Mansehra and Balakot areas of Hazara, Pakistan and their major geotechnical properties determined following the standard ASTM procedures. The determined properties include the Atterberg limits, i.e. Liquid Limit (LL), Plastic Limit (PL), Plasticity Index (PI), and Maximum dry density, Optimum moisture contents, Un-confined compressive strength, Activity and Expansion. Both the soils are classified as active soils possessing high expansion capacity and low strength due to the presence of Ca-montmorillonites. Following an increment of 5\%, up to $25 \%$ streaks of cutting waste from Susalgali and Baffa granites were added to the Mansehra soil and Balakot soil respectively. A thorough analysis of the test results reveals a continuous decrease in the Atterberg limits, optimum moisture contents and expansion capacity, and increase in the maximum dry density and overall strength of both the soils with increasing amounts of the added granite cutting waste streaks. The reduction in Atterberg limits, optimum moisture contents and expansion capacity reflects the low activity and lower absorption capacity of the added granite. Besides, the concomitant increase in strength and maximum dry density of the treated soils suggests suitability of granite waste addition as a potential means for enhancing bearing capacity and reducing settlement issues in civil engineering.
\end{abstract}

Key words: Granite cutting waste, Soil treatment, Granite streak, Atterberg's limits, Activity, Expansion, Optimum moisture contents, Maximum dry density, Un-confined compressive strength.

\section{INTRODUCTION}

The management of soils for their cost-effective use in construction is essentially a challenge in geotechnical engineering practice [1]. The durability and performance of an engineering structure depend on the strength of the underlying soils;weak soils can create severe problems. Cohesive soils commonly occur in most of the arid and semi-arid regions of the world. Owing to high plasticity and greater susceptibility to cyclic swell-shrink/expansive behavior, cohesive soilscan pose severe threat to the structures founded on them [2]. This behavior of a soil depends on its Activity, which is the ratio between its plasticity index and clay fraction. Plasticity index is the numerical difference between Liquid and Plastic limits. That is why the liquid limit, plastic limit and plasticity index are widely used for predicting the engineering behavior of cohesive soils [3]. On the basis of Activity, Skempton [4] has divided soils into inactive, normal and active types with activity 0.75, 0.75-1.25 and more than 1.25, respectively.

Soils containing Ca-montmorillonite and Na-montmorillonite possess high expansion and low bearing capacity and are referred to as active soils. As construction on such soils is known to produce severe disastrous effects through early settlement, proper stabilization is required before initiating construction on them. Stabilization or treatment of soil is the technique employed to soils with low bearing and high expansion capacities for making them more stable by improving their bearing capacity and durability under adverse moisture and stress conditions [5]. Several studies are available in which cohesive and active soils were successfully stabilized through an addition of different types of material including barite powder [6], fly ash [7], phosphor gypsum 
[8], pyroclastic dust [9], lime [10], cement kiln dust [11], silica fume [12], ground polyvinyl waste [13], ash and phosphor-gypsum [14], RHA and Portland slag cement[15], and a mixture of sand (22.44\%), flyash (13.2\%)and marble dust (12\%) to soil (52.36\%) [16].

In running days, the stone factories create huge amounts of industrial waste through cutting processes. The waste contains toxic elements and thus causes serious threats to the environment by effecting both surface and ground waters. Fortunately, the extent of the environmental impact could be reduced by properly utilizing the waste.

The current study analyzes the influence of granite cutting waste addition on the plasticity, maximum dry density, optimum moisture contents, unconfined compressive strength, activity and expansion of cohesive soils. Specifically, different proportions of cutting waste from the Susalgali and Mansehra granites were used as stabilization admixtures in the cohesive soils of the Mansehra and Balakot regions in a bid to make them less active, less expansive and thus stronger and more stable to avoid settlement issues. The outcomes of the study are expected to help resolve major issues of environmental and geotechnical concerns by suggesting utilization of granite cutting waste for improving the quality of cohesive soils.

\section{METHODOLOGY}

A detailed field survey was conducted to locate suitable sites for collecting representative samples of soil and granite cutting waste from Mansehra region, Hazara, Pakistan. Two samples of granite cutting waste were collected, i.e. one sample each from Susalgali and Baffa (Fig. 1). Both the collected samples are coarse grained and essentially consist of more or less similar modal proportions of alkali feldspar, quartz and plagioclase, however the Baffa granite is darker because of its slightly higher content of dark colored (mafic) minerals, mainly biotite, than the Susalgali sample. Following crushing and grinding, the granite cutting waste samples were passed through sieve \#200 to obtain a fine streak. Two soil samples, one each from Mansehra and Balakot areas, were collected and named accordingly as Mansehra soil and Balakot soil, respectively. The soil samples were also passed through \#200 sieves to obtain fractions finer than 200 mesh.

Six samples of the Mansehra soil were prepared by adding to them streak of Susalgali granite cutting waste in different proportions (Table 1). In the same way, six samples of the Balakot soil were prepared by mixing with streak of Baffa granite cutting waste in different proportions. Different properties including the liquid limit, plastic limit, plasticity index, maximum dry density, optimum moisture contents, unconfined compressive strength, activity and expansion of each of the resulting twelve samples were then determined. Employing the ASTM D7928 method [19], hydrometer analysis was performed to determine modal mineralogical composition of the original soil samples from the Mansehra and Balakot areas. The Atterberg limits (i.e. liquid limit, plastic limit and plasticity index) of the original and granite waste treated samples of the Mansehra and Balakot soils were determined with the ASTM D4318 procedure [20]. Maximum dry density and optimum moisture contents were determined by using standard proctor test of the ASTM D698 [21]. The unconfined compressive strength was determined by the ASTM D2166 method [22]. The activity values of all the studied samples were calculated with the equation:

Activity = Plasticity index/Clay content [4].

Table 1: Details of the treatment process of the studied soil samples

\begin{tabular}{|c|c|c|}
\hline Sample Number & Percentage of soil & $\begin{array}{c}\text { Percentage of the added granite } \\
\text { cutting waste }\end{array}$ \\
\hline 1 & 100 & 0 \\
\hline 2 & 95 & 10 \\
\hline 3 & 90 & 15 \\
\hline 4 & 85 & 20 \\
\hline 5 & 80 & 25 \\
\hline 6 & 75 & \\
\hline
\end{tabular}


International Journal of Engineering Research And Advanced Technology, Vol.5, Issue 7, July2019

Geological Map of Mansehra and Surroundings

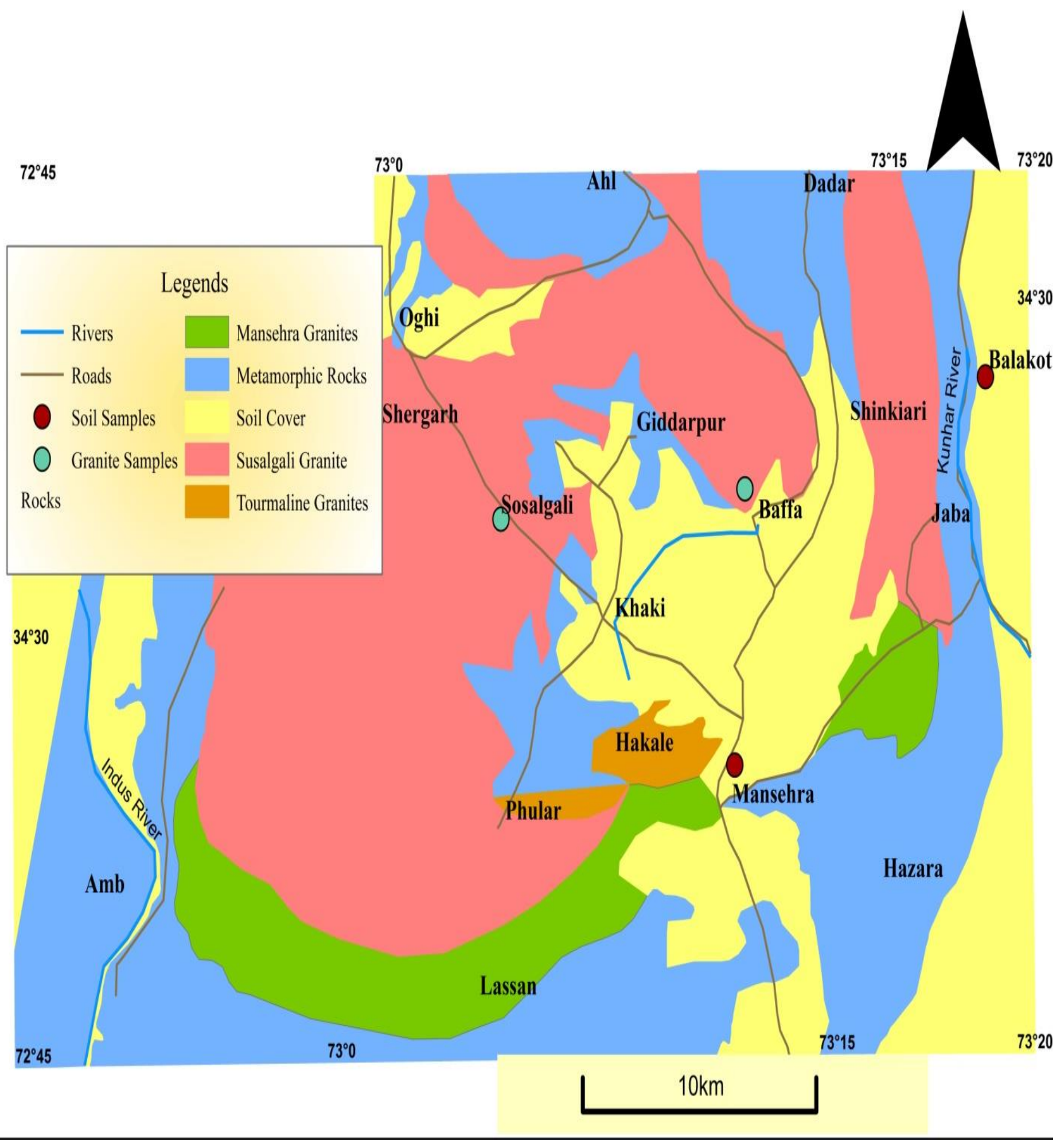

Figure 1: Sample location and geological map of the study area (after Shams, 1967) 


\section{RESULTS}

\section{Hydrometer analysis}

Hydrometer analysis was carried out to determine the modal mineralogical composition of the original soil samples from the Mansehra and Balakot areas. The results reveal that the Mansehra soil consists of $25.2 \%$ clay and $74.8 \%$ silt, while the corresponding components in the soil from Balakot are $21.1 \%$ and $78.9 \%$, respectively.

\section{Geotechnical Parameters}

The liquid limit and plastic limit of the original (untreated) Mansehra and Balakot soil samples are high. However, both these parameters are gradually reduced with progressive increase in the proportions of the added cutting waste (Tables 2 and 3; Fig. 2). Owing to their derivation from the liquid limit and plastic limit, the values of plasticity index for both the Mansehra and Balakot soil samples are gradually decreased with increase in the amount of the added granite waste (Tables 2 and 3; Fig. 2).

Increase in the amount of the added granite also causes a regular reduction in the activity and optimum moisture contents of both the Mansehra and Balakot soils, whereas the values of their unconfined compressive strength and maximum dry density are increased (Tables 2 and 3; Fig. 2).

The expansion capacity of the studied samples was determined with the help of the relevant published chart (Fig. 3). The plot demonstrates that the untreated Mansehra and Balakot soils possess high expansion capacity since they contain Camontmorillonite. However, the samples treated by adding up to $25 \%$ granite cutting waste show reduction in their expansion capacity to medium level.

Table 2: Properties of the untreated and treated Mansehra soil samples

\begin{tabular}{|l|c|c|c|c|c|c|c|}
\hline Samples & Liquid Limit & Plastic Limit & Plasticity Index & Activity & $\begin{array}{c}\text { Optimum } \\
\text { moisture } \\
\text { contents } \\
\text { (\%) }\end{array}$ & $\begin{array}{c}\text { Maximum } \\
\text { dry density } \\
\text { (g/cm3) }\end{array}$ & $\begin{array}{c}\text { Unconfined } \\
\text { compressiv } \\
\text { e strength } \\
\text { (KPA) }\end{array}$ \\
\hline $\begin{array}{l}\text { Sample 1 } \\
\text { (100\% Mansehra } \\
\text { soil) }\end{array}$ & 66.03 & 32.01 & 34.02 & 1.35 & 27 & 1.46 & 17.1 \\
\hline $\begin{array}{l}\text { Sample 2 } \\
\text { (Mansehra soil+ 05\% } \\
\text { Susalgali granite } \\
\text { cutting waste) }\end{array}$ & 61.1 & 29.7 & 31.4 & 1.246 & 25.1 & 1.49 & 20.7 \\
\hline $\begin{array}{l}\text { Sample 3 } \\
\text { (Mansehra soil+ 10\% } \\
\begin{array}{l}\text { Susalgali granite } \\
\text { cutting waste) }\end{array}\end{array}$ & 56.1 & 27.2 & 28.9 & 1.140 & 23.6 & 1.56 & 26.9 \\
\hline $\begin{array}{l}\text { Sample 4 } \\
\text { (Mansehra soil+ 15\% } \\
\text { Susalgali granite } \\
\text { cutting waste) }\end{array}$ & 50.1 & 24.01 & 26.09 & 1.035 & 21.9 & 1.63 & 27.7 \\
\hline $\begin{array}{l}\text { Sample 5 } \\
\text { (Mansehra soil+ 20\% } \\
\text { Susalgali granite } \\
\text { cutting waste) }\end{array}$ & 45.07 & 21.6 & 23.47 & 0.93 & 18.7 & 1.71 & 31.4 \\
\hline $\begin{array}{l}\text { Sample 6 } \\
\text { (Mansehra soil+ 25\% } \\
\text { Susalgali granite } \\
\text { cutting waste) }\end{array}$ & 39.09 & 19.3 & 19.3 & 0.79 & 15.4 & 1.78 & 35.1 \\
\hline
\end{tabular}


International Journal of Engineering Research And Advanced Technology, Vol.5, Issue 7, July2019

Table 3: Properties of the untreated and treated Balakot soil samples

\begin{tabular}{|l|c|c|c|c|c|c|c|}
\hline Samples & Liquid Limit & Plastic Limit & Plasticity Index & Activity & $\begin{array}{c}\text { Optimum } \\
\text { moisture } \\
\text { contents } \\
\text { (\%) }\end{array}$ & $\begin{array}{c}\text { Maximum } \\
\text { dry density } \\
\text { (g/cm3) }\end{array}$ & $\begin{array}{c}\text { Unconfined } \\
\text { compressive } \\
\text { strength } \\
\text { (KPA) }\end{array}$ \\
\hline $\begin{array}{l}\text { Sample 1 } \\
\text { (100\% Balakot soil) }\end{array}$ & 61.9 & 33.50 & 28.4 & 1.34 & 29 & 1.39 & 21.1 \\
\hline $\begin{array}{l}\text { Sample 2 } \\
\text { (Balakot soil + 05\% } \\
\text { Baffa granite } \\
\text { cutting waste) }\end{array}$ & 56.71 & 31.09 & 25.62 & 1.21 & 28.1 & 1.42 & 22.9 \\
\hline $\begin{array}{l}\text { Sample 3 } \\
\text { (Balakot soil + 10\% } \\
\text { Baffa granite } \\
\text { cutting waste) }\end{array}$ & 52.1 & 28.7 & 23.40 & 1.10 & 26.3 & 1.48 & 27.3 \\
\hline $\begin{array}{l}\text { Sample 4 } \\
\text { (Balakot soil + 15\% } \\
\text { Baffa granite } \\
\text { cutting waste) }\end{array}$ & 48.2 & 25.07 & 23.13 & 1.09 & 23.9 & 1.53 & 32.1 \\
\hline $\begin{array}{l}\text { Sample 5 } \\
\text { (Balakot soil + 20\% } \\
\text { Baffa granite } \\
\text { cutting waste) }\end{array}$ & 44.07 & 22.31 & 21.76 & 1.03 & 20.5 & 1.61 & 34.9 \\
\hline $\begin{array}{l}\text { Sample 6 } \\
\text { (Balakot soil + 25\% } \\
\text { Baffa granite } \\
\text { cutting waste) }\end{array}$ & 39.01 & 20.2 & 18.81 & 0.89 & 17.4 & 1.66 & 39.6 \\
\hline
\end{tabular}

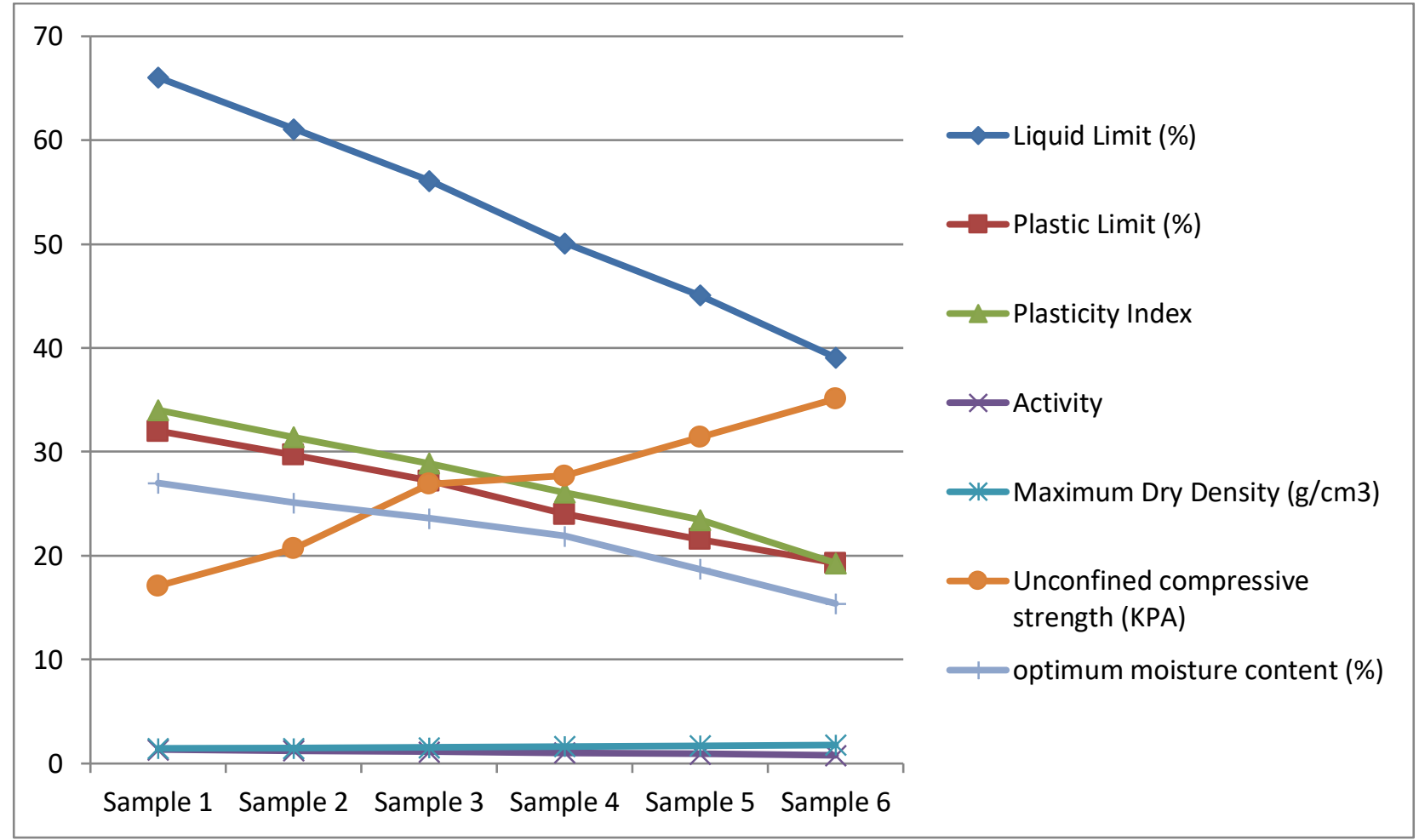

Figure 2.A 




Figure 2.B

Figure 2: Variation in the geotechnical parameters of the original and treated Mansehra (a) and Balakot (b) soil samples



Figure 3.A 


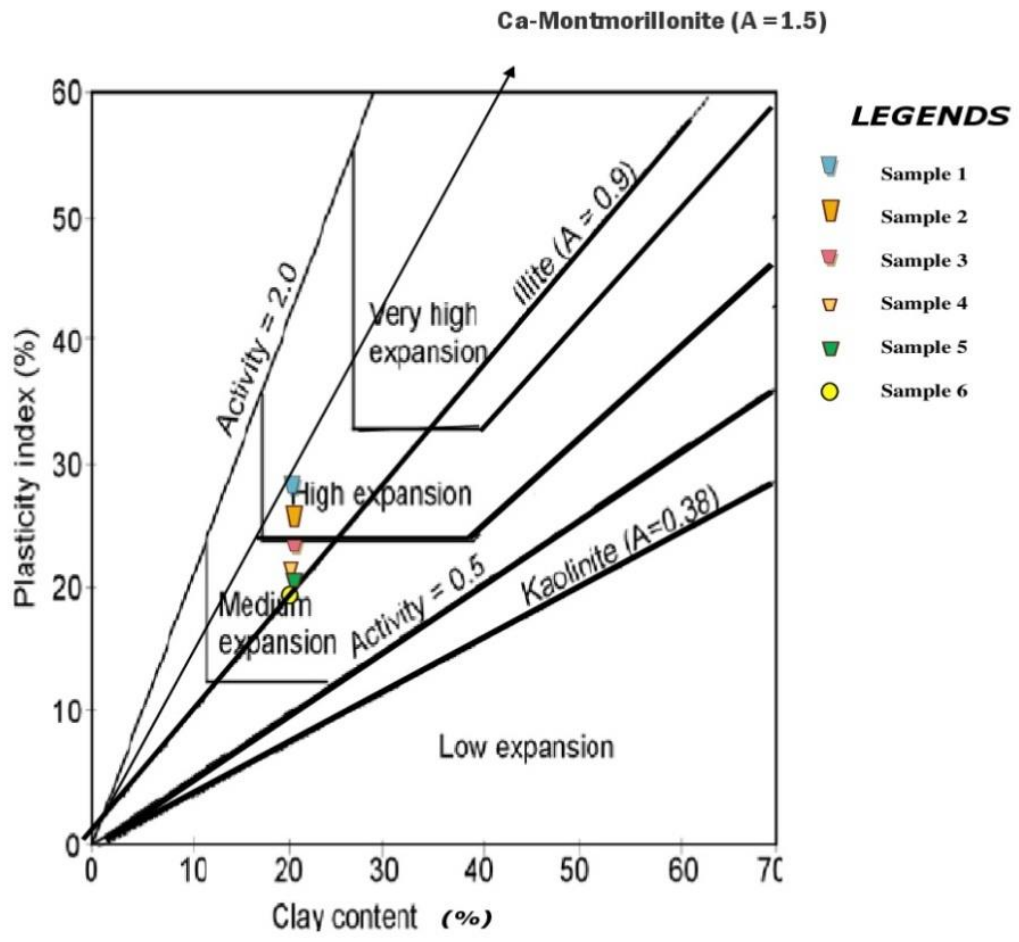

Figure 3.B

Figure 3: Activity chart showing the expansion capacity of the original and variously treated Mansehra (a) Balakot (b) soil samples.

\section{CHARACTERIZATION}

The AASHTOO and Unified soil classification schemes were used to properly characterize the samples of Mansehra and Balakot soils. As demonstrated, the original (untreated) soils from both the Mansehra and Balakot areas plot in the group of soils with fair to poor strength (i.e. soils A7-6). The addition of increasing amounts of the granites cutting waste changes the character of the treated samples through type A- 6 to A2-6 (Fig. 4). The strength of A2-6 soils falls between excellent and good. Plotting on the Unified soil classification system reveals that the untreated samples from both the Mansehra and Balakot areas belong to $\mathrm{CH}$ type, i.e. FAT soils. However, the gradual addition of granite waste regularly upgrades the resulting treated samples to the group of CL, i.e. less active soils (Fig.5).

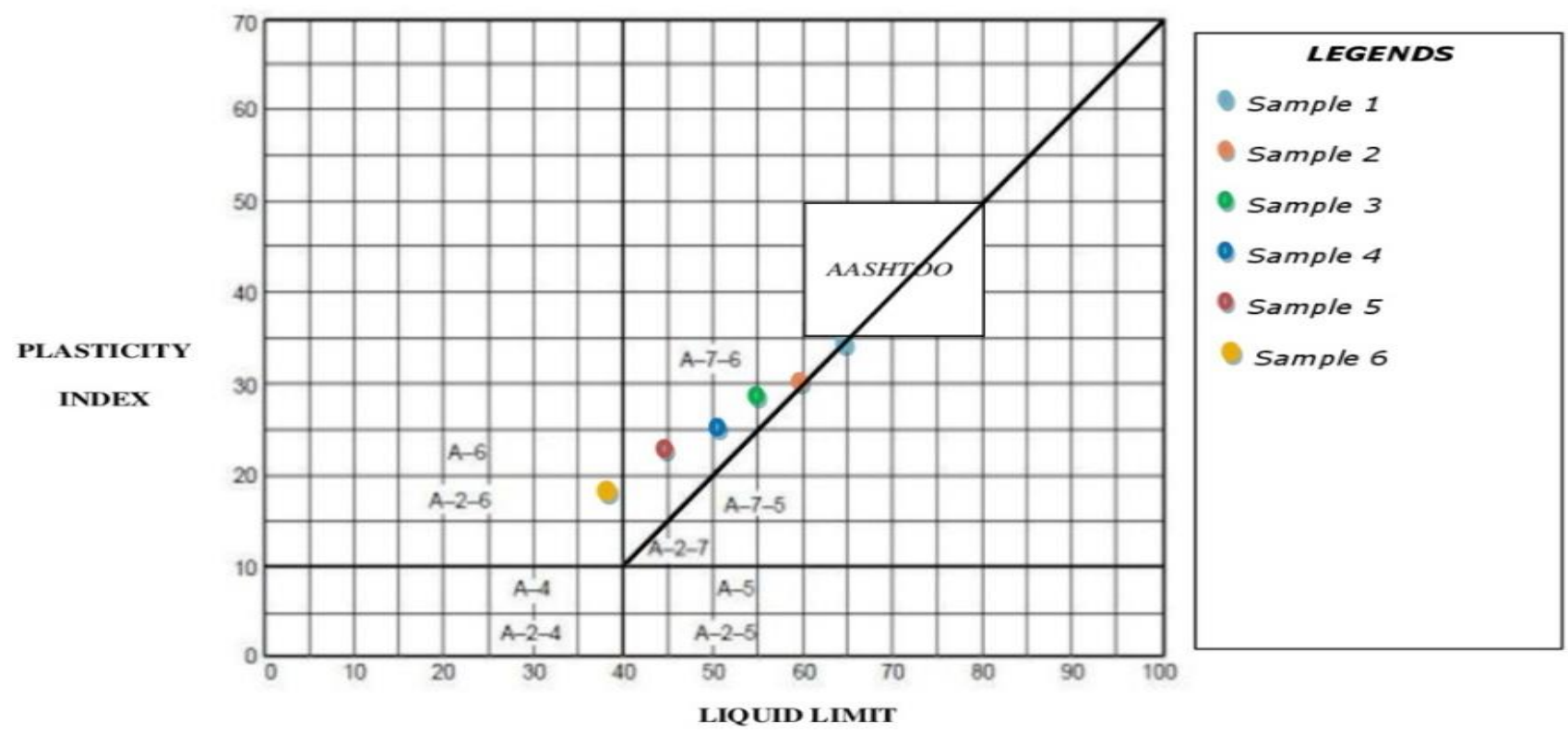

Figure 4.A 
International Journal of Engineering Research And Advanced Technology, Vol.5, Issue 7, July2019

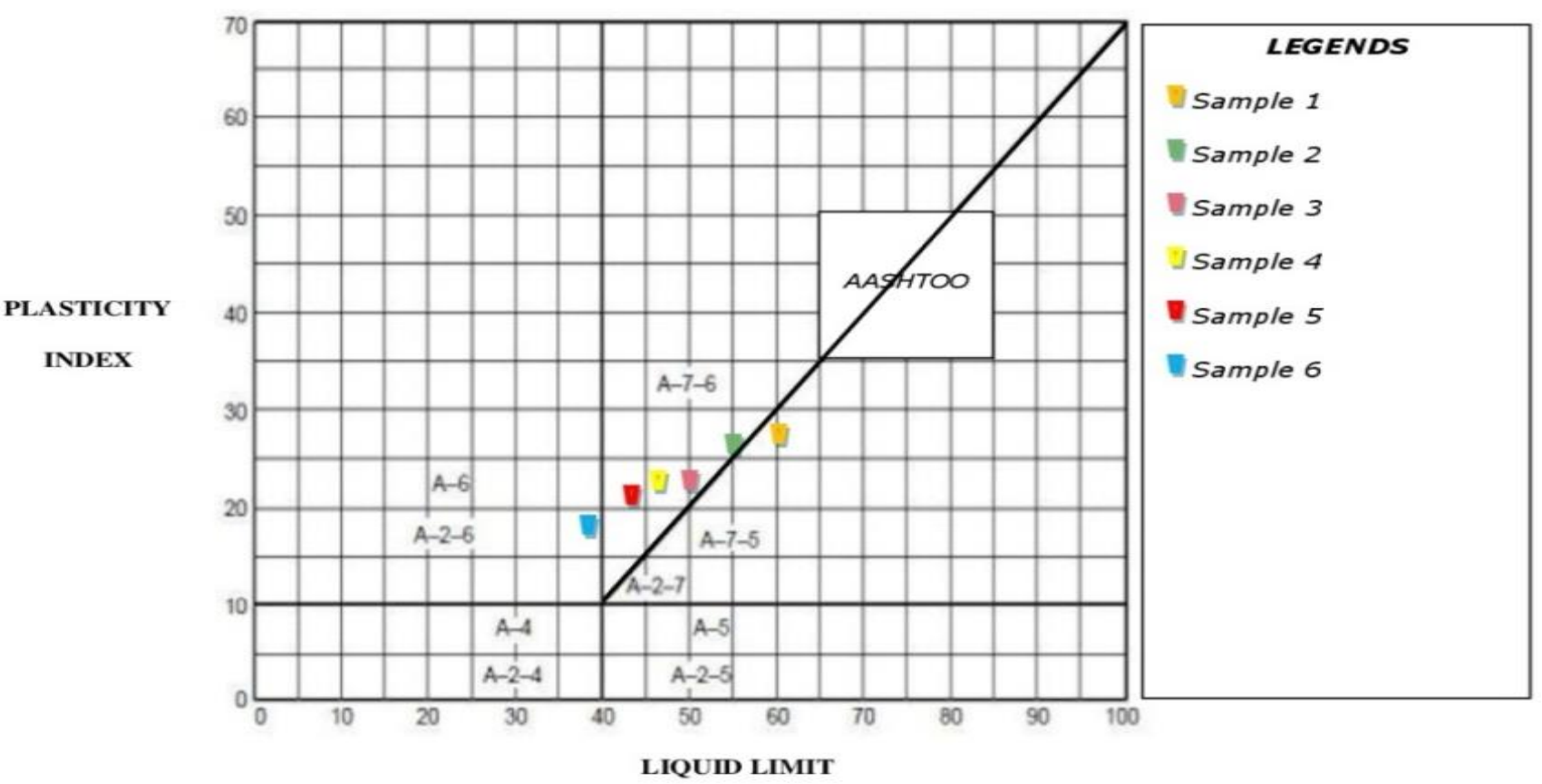

Figure 4.B

Figure 4: Characterization of the original and variously treated Mansehra (a) Balakot (b) soil samples using the AASHTOO plasticity chart.

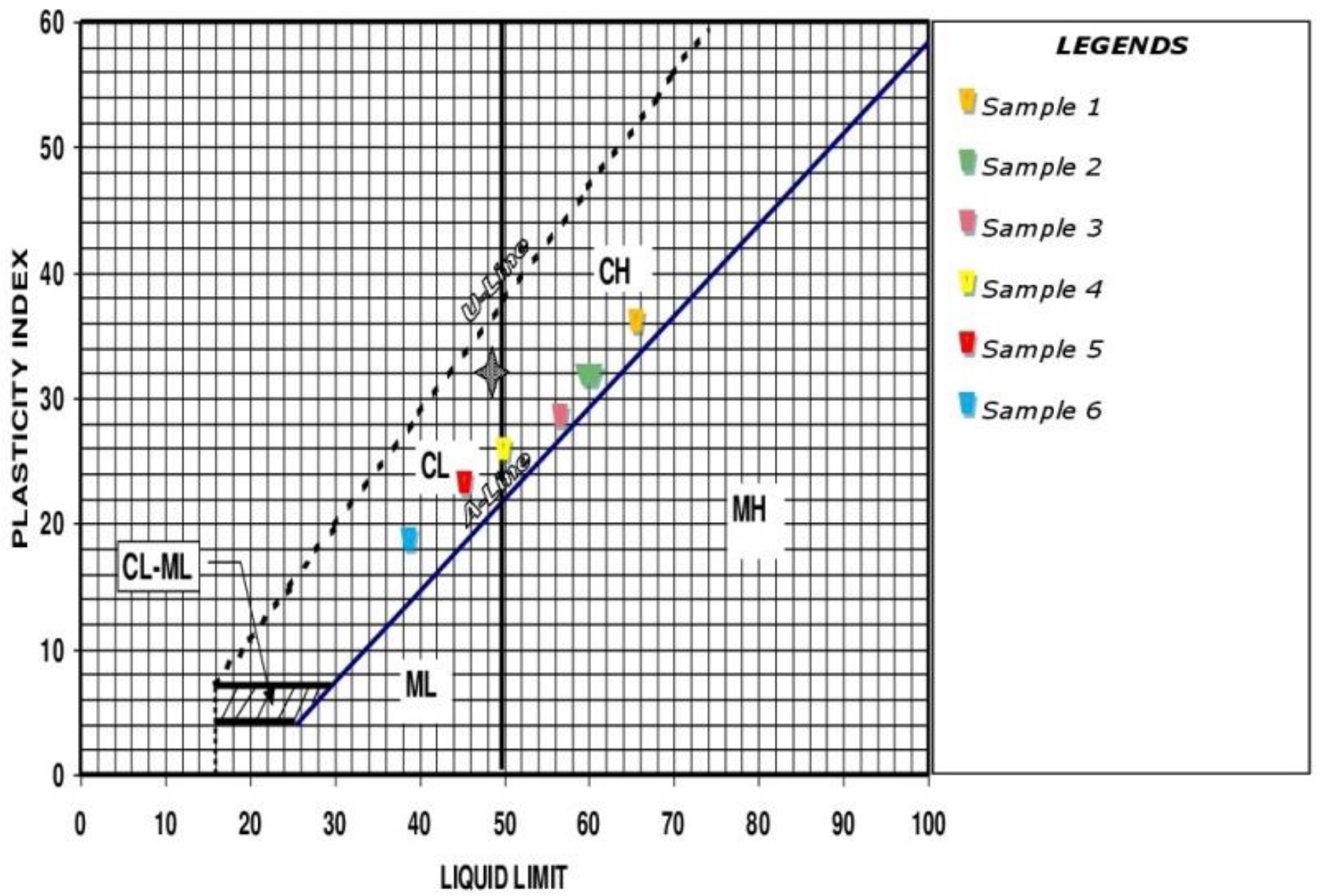

Figure 5.A 

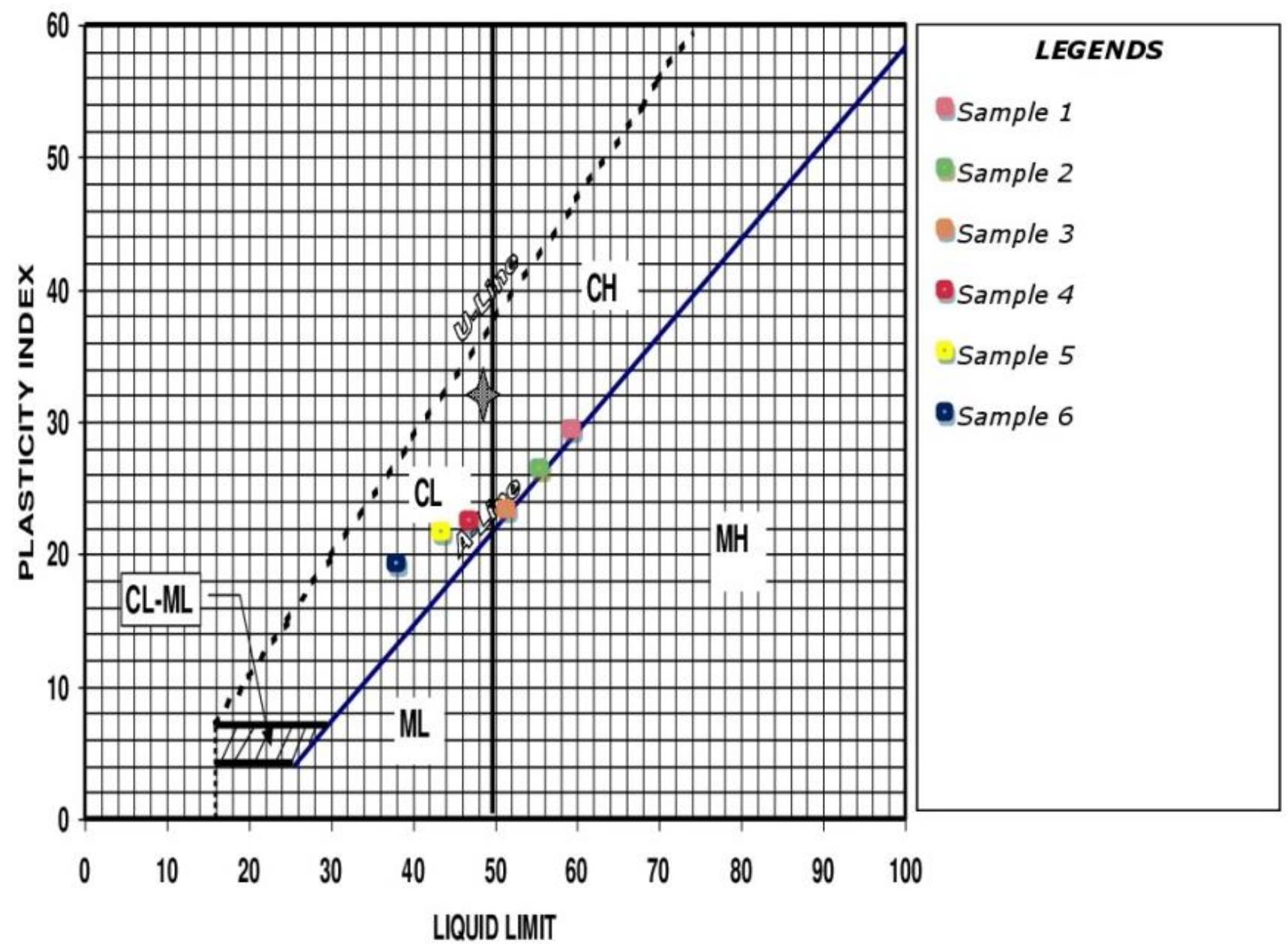

Figure 5.B

Figure 5: Characterization of the original and variously treated Mansehra (a) Balakot (b) soil samples using the Unified plasticity chart. Symbols used in chart shows $\mathrm{CH}=$ Fat clays having high plasticity, $\mathrm{MH}=\mathrm{Elastic}$ silts, $\mathrm{ML}=\mathrm{Clayey}$ silts of low plasticity, $\mathrm{CL}=$ Silty clays, Non active clays

\section{DISCUSSION}

Activity, Compaction, Strength, Liquid Limit, Plastic Limit and Plasticity index need to be properly investigated prior to designing structures and their foundation as they control the soil performance in response to applied load. The investigated soil samples from both the Mansehra and Balakot areas display higher values of liquid limit and plastic limit due to their content of Ca-montmorillonite (Fig.3). The Ca-montmorillonite is known to absorb and hold a significant amount of water in their inter-ionic layers, causing swelling and bringing about changes in interlayer spacing. The high values of liquid and plastic limits lead to an increase in plasticity index that in turn enhances the activity and hence the expansion capacity of soils. Based on these parameters, the soils under investigation are categorized as active soils having high expansion. Addition of cutting waste from the Susalgali and Baffa granites has led to reduction of the values of liquid limit, plastic limit, plasticity index, optimum moisture content and activity of the Mansehra and Balakot soils. This is because such a treatment results in diluting the concentration of more active, cohesive and more absorptive components (e.g. Ca-montmorillonite) and increasing the abundance of very much less active, noncohesive and less absorptive minerals (quartz, feldspars and micas) from the added granite (Table 4). Likewise, the high specific gravity of Baffa and Susalgali granites is most likely a reason for enhancing the values of maximum dry density (MDD) and unconfined compressive strengths of the studied soils. Being predominantly composed of stronger minerals with very low absorption capacity (i.e. quartz and feldspars), the Baffa and Susalgali granites display very low values of water absorption, 0.98 $\%$ and $1.16 \%$, respectively and high values of compressive (1641 Psi and 1595 Psi, respectively) and tensile strengths (198 Psi and $240 \mathrm{Psi}$, respectively) [23]. That is why their addition of these has resulted in improving the Atterberg limits, compaction parameters, unconfined compressive strength, activity and expansion, and hence performance of the investigated soils. 
International Journal of Engineering Research And Advanced Technology, Vol.5, Issue 7, July2019

Table 4: Activity values of expected minerals in soils

\begin{tabular}{|c|c|c|}
\hline Mineral & Activity & Reference \\
\hline Quartz & 0.00 & \multirow{2}{*}{ Von Moos (1938) } \\
\hline Calcite & 0.18 & \multirow{2}{*}{ Northey (1950) } \\
\hline Mica (Muscovite) & 0.23 & \multirow{2}{*}{ Samuls (1950) } \\
\hline Kaolinite & 0.33 & 0.90 \\
\hline Illite & 1.50 & \\
\hline Ca-Montmorillonite & 7.20 & \\
\hline
\end{tabular}

\section{CONCLUSIONS}

1) The addition of up to $25 \%$ granite cutting waste as streak improves the quality of cohesive soils significantly by drastically reducing their Atterberg limits, optimum moisture contents, activity and expansion capacity.

2) Such a treatment enhances also the performance and sustainability of cohesive soils by increasing their maximum dry density and unconfined compressive strengths.

3) This treatment plays a key role to control the negative impact of granite cutting waste on the environment.

\section{REFERENCES}

[1] Ogbonnaya, I and David, D. "The Potential effect of Granite Dust on the Geotechnical Properties of Abakaliki clays". Continental J. Earth sciences, Vol. 6(1), 2011, pp 23.30.

[2] Sabat, A.K and Muni, P.K. "Effects of Limestone Dust on Geotechnical Properties of an Expansive Soil". International Journal of Applied Engineering, Vol. 10(17), 2015, pp 37724-37730.

[3] Polidori, Ennio. "Relationship between the atterberg limits and clay content". Soils and Foundations -Tokyo-. 47. 2007, pp 887-896. 10.3208/sandf.47.88.

[4] Skempton, A. W. "A possible relationship between true cohesion and the mineralogy of clays". Proc. 2nd Int. Conf. S.M., Vol. 7, 1948, p. 45.

[5] Joel,M.and Agbede,I.O. "Mechanical-Cement Stabilization of Laterite for Use as Flexible Pavement Material".Journal of Materialsin Civil Engineering, Vol. 23 (2), 2011, pp. 146-152.

[6] Srinivasulu, G. and Rao, A.V.N. "Efficacy of Baryte Powder as a Soil Stabiliser". Journal of Institution of Engineers (I), 76, 1995, pp 129-131.

[7] Pandian, N. S., Krishna, K. C. and Sridharan, A. "California Bearing Ratio Behavior of Soil/Fly ash Mixtures". Journal of Testing and Evaluation, Vol. 29(2), 2001, pp. 220-226.

[8] Mishra, J., Yadav, R.K. and Singhai, A.K. "Effect of Granite Dust on Index Properties of Lime Stabilized Black Cotton Soil". International Journal of Engineering Research and Science \& Technology, Vol. 3 (1), 2014, pp. 19-23.

[9] Ene, E. and Okagbue, C. "Some Basic Geotechnical Properties of Expansive Soil Modified using Pyroclastic Dust”.Engineering Geology, Vol. 107, 2009, pp 61-65.

[10] Sabat, A.K."Statistical Models for Prediction of Swelling Pressure of a Stabilized Expansive Soil". Electronic Journal of Geotechnical Engineering, Vol. 17(G), 2012, pp 837-846.

[11] Moses, G.K. and Saminu, A. "Cement Kiln Dust Stabilization of Compacted Black Cotton Soil". Electronic Journal of Geotechnical Engineering, Vol. 17(F), 2012, pp. 825-836.

[12] Negi, C., Yadav, R.K. and Singhai, A.K. "Effect of Silica Fume on Index Properties of Black Cotton Soil". International Journal of Scientific and Engineering Research, Vol. 4(8), 2013, pp. 828-832.

[13] Oyekan, G.L., Meshida, E.A. and Ogundalu, A.O. "Effect of Ground Polyvinyl Waste on the Strength Characteristics of Black Cotton Clay Soil". Journal of Engineering and Manufacturing Technology, Vol. 1, 2013, pp. 1-10.

[14] Krishnan, R, G., Anjan Kumar, M. and Prasad Raju, G.V.R. "Swelling Properties of Expansive Soils Treated with Chemicals and Fly Ash". American Journal of Engineering Research, Vol. 3(4), 2014, pp. 245-250.

[15] Ashango, A.A. and Patra, N.R. "Static and Cyclic Properties of Clay Subgrade Stabilised with Rice Husk Ash and Portland Slag Cement". International Journal of Pavement Engineering, 2014.

[16] Gupta, C. and Sharma, R.K. "Influence of Marble Dust, Fly Ash and Beach Sand on Sub-Grade Characteristics of Expansive Soils". International Conference on Advances in Engineering and Technolog, IOSR Journal of Mechanical and Civil Engineering, 2014, pp. 13-18.

[17] Trade development authority of Pakistan. "A report on marble and granite". 
[18] Hamza, Rania \& El-Haggar, Salah \& Khedr, Safwan. "Marble and Granite Waste: Characterization and Utilization in Concrete Bricks". International Journal of Bioscience, Biochemistry and Bioinformatics. 1. 2011, $286-291$. 10.7763/IJBBB.2011.V1.54.

[19] ASTM D7928-17, "Standard Test Method for Particle-Size Distribution (Gradation) of Fine-Grained Soils Using the Sedimentation (Hydrometer) Analysis". ASTM International, West Conshohocken, PA, 2017.

[20] ASTM D4318. "Standard test methods for liquid limit, plastic limit and plasticity index of soils". West Conshohocken, PA, USA: ASTM International; 2000.

[21] ASTM D698. "Standard test method for laboratory compaction characteristics of soil using standard effort".West Conshohocken, PA, USA: ASTM International; 2000

[22] ASTM D2166-06, "Standard Test Method for Unconfined Compressive Strength of Cohesive Soil". ASTM International, West Conshohocken, PA, 2006

[23] Arif. M., Mulk, A., Mehmood, T, M., Shah, H, M., "Petrography and mechanical properties of mansehra granite, Hazara, Pakistan". Geol. Bull. Univ. Peshawar, Vol. 32, 1999, pp. 41-49.

[24] Moos, A. von. "Geotechnical properties and investigation methods of loose rocks".Earthwork course of E.T.H. N o. 4 (Zurich), 1938. Thesis Faculty of Science.1950, University of London.

[25] Northey, R. D. "An experimental study o f the structural sensitivity o f clays". Ph.D.

[26] Samuels, S. G. "The effect o f base exchange on the engineering properties of soils". Building Res. Station Note, No. C176 (Watford), 1950.

[27] Shams, F. A. "Granites of the Mansehra-Amb state area and the associated metamorphic rocks". Unpubl ., 1967, Ph. D. thesis, Univ. Punjab, Lahore.

[28] American Association of State Highway and Transportation officials, AASHTO Materials. Part 1. Specifications.1982, Washington, D.C.

[29] American Association of State Highway and Transportation officials, Annual book of ASTM Standards. Sec.4. Vol. 04.08.1999, West Conshohoken, Pa. 